\title{
PENGARUH KEPEMILIKAN MANAJERIAL, KEPEMILIKAN INSTITUSIONAL DAN KEBIJAKAN DEVIDEN TERHADAP NILAI PERUSAHAAN
}

(Studi kasus pada Perusahaan Otomotif \& Komponen yang Terdaftar di Bursa Efek Indonesia)

\author{
Nafanda Hafsah Nur Azizah
}

Fakultas Ekonomi Universitas Sarjanawiyata Tamansiswa Yogyakarta

Email: nafandahafsah228@gmail.com

\begin{abstract}
Intisari
Penelitian ini bertujuan untuk mengkaji dan menganalisis pengaruh kepemilikan manajerial, kepemilikan institusional dan kebijakan Dividen terhadap nilai perusahaan. Penelitian ini menggunakan perusahaan otomotif dan komponen yang terdaftar di Bursa Efek Indonesia (BEI) dengan periode pengamatan tahun 2014-2018. Teknik yang digunakan dalam pengambilan sampel menggunakan pusposive sampling dan poling data. Alat analisis yang digunakan adalah regresi linier berganda dengan bantuan software SPSS 23. Berdasarkan analisis yang telah dilakukan diperoleh hasil bahwa variabel kepemilikan manajerial (KM) berpengaruh positif dan tidak signifikan terhadap nilai perusahaan (Price to Book Value). Kepemilikan Institusional (KI) berpengaruh negatif dan tidak signifikan terhadap nilai perusahaan (Price to Book Value). Kebijakan Dividen (Dividend Payout Ratio) berpengaruh positif dan signifikan terhadap nilai perusahaan (Price to Book Value) sedangkan kepemilikan manajerial, kepemilikan institusional dan kebijakan Dividen secara bersama-sama atau simultan berpengaruh positif dan signifikan terhadap nilai perusahaan.
\end{abstract}

Kata Kunci: Kepemilikan Manajerial, Kepemilikan Institusional, Kebijakan Dividen, Nilai Perusahaan

\section{Abstract}

This study aims to examine and analyze the effect of managerial ownership, institutional ownership and dividend policy on firm value. This study uses automotive companies and components listed on the Indonesia Stock Exchange (IDX) with an observation period of 2014-2018. The technique used in sampling uses pusposive sampling and data polling. The analytical tool used is multiple linear regression with the help of SPSS 23 software. Based on the analysis that has been done, the results show that the managerial ownership variable (KM) has a positive and not significant effect on the value of the company (Price to Book Value). Institutional Ownership (KI) has a negative and not significant effect on company value (Price to Book Value). Dividend Policy (Dividend Payout Ratio) has a positive and significant effect on firm value (Price to Book Value) while managerial ownership, institutional ownership and dividend policy together or simultaneously have a positive and significant effect on firm value.

Keywords: Managerial Ownership, Institutional Ownership, Dividend Policy, Company Value

\section{PENDAHULUAN}

Terdapat banyak perusahaan yang tumbuh dan berkembang di Bursa Efek Indonesia salah satu diantaranya ialah perusahaan otomotif dan komponen. Hal ini bisa dilihat dari semakin banyaknya produk-produk dari perusahaan otomotif dan komponen yang digunakan baik dari jenis ataupun jumlahnya (Ermiati, Amanah, Harahap, \& Siregar, 2019). Banyaknya jenis kendaraan yang terjual dipasaran berasal dari kepercayaan konsumen pada perusahaan otomotif ternama, perusahaan-perusahaan otomotif ini terus melakukan inovasi-inovasi baru dan kreatif, perkembangan ini terlaksana karna adanya minat investor dalam berinvestasi. 
Dalam berinvestasi yang paling penting dilihat oleh investor adalah persepsinya terhadap perusahaan, dihubungkan dengan harga saham. Tingginya nilai perusahaan disebabkan oleh tingginya harga saham (Yahdi \& Dewi, 2015). Situasi ini searah dengan misi perusahaan. Cermin dari kesejahteraan pemegang saham ada pada nilai perusahaan. Para perusahaan yang sudah terdaftar di Bursa Efek Indonesia merefleksikan nilai perusahaan lewat harrga pasar saham. Salah satu harga yang dapat dijadikan proksi bagi nilai perusahaan adalah harga pasar karena harga pasar merupakan harga yang telah disepakati untuk dibayarkan oleh para calon investor. Cerminan kemampuan unit bisnis sesungguhnya merupakan harga saham karena mendatangkan keuntungan yang telah dipergunakan untuk kepentingan perusahaan secara efektif, oleh karena itu naiknya margin perusahaan akan selaras dengan naiknya nilai perusahaan (Wright dan Ferris, 1997 dalam Fenandar 2012).

Demi mencapai tujuan perusahaan tersebut pada umumnya pemilik modal memberi kepercayaan manajemen perusahaan pada tenaga ahli manajerial yang sering disebut agen atau insiders. Tanggung jawab manajerial akan mencakup tiga hal. Yang perrtama, strategi untuk mengoptimurmkan perolehan sumber dana. Yang kedua, mengetahui kebijakan alokasi dana yang paling menguntungkan antara kepentingan bisnis atau investasi baik modal yang bersumber dari dalam perusahaan (internal financing) mau pun modal yang bersumber dari luar perusahaan (external financing). Yang ketiga adalah mengenai keputusan dividen.

Salah satu cara untuk misahkan kekuasaan dalam decision making dan risk bearing adalah dengan memberikan kepercayaan kepada insider. Upah dan fasilitas lain akan diberikan pada manajer sebagai bentuk penghargaan atas kepercayaan dalam pembuatan kebutusan yang baik tentunya untuk menjaga dana investor tetap aman didalam perusahaan. Tetapi fakta di lapangan seringkali tidak sejalan karena tidak maksimalnya kinerja manajer dalam melakssanakan fungsinya untuk meningkatnya nilai perusahaan karena manajer lebih cenderung untuk memikirkan kemakmuran dirinya sendiri. Hal seperti ini dinamakan sebagai agency conflict, dimana keinginan pemilik bertentangan dengan manajer. Misalnya pemilik lebih suka hutang daripada equity perihal pemakaian sumber dana, sedangkan manajer lebih memandang bila hutang mempunyai risiko lebih yang akan menjadi beban bagi insiders dalam hal pemakaian sumber dana. Hal ini adalah salah satu konflik yang sering terjadi.

Mensejajarkan kepentingan pemilik dan kepentingan manajer adalah salah satu upaya perusahaan untuk mengatasi masalah ini.Untuk mengawasi biaya keagenan yang muncul oleh pihak agen, upaya yang ditempuh agar perusahaan mampu menghasilkan laporan keuangan dengan informasi laba yang berbobot dilakukan melalui prosedur good corporate governance yang tidak lain adalah alat tidak langsung bagi pihak prinsipal. Prosedur yang sering digunakan dalam beberapa kajian mencakup good corporate governance, diantaranya ialah kepemilikan institusional dan kepemilikan manajerial perusahaan (Nuraina, 2012 dalam Wida P.D \& Suartana, 2014).

Karena tingkat kepentingan dalam pemenuhan pencapaian target pribadi sangat tinggi tidak sedikit jajaran manajer yang ikut terjun menjadi pemegang saham diperusahaan yang dioperasikannya sendiri, hal seperti ini dinamakan insider ownership (kepemilikan manajerial). Kepemilikan manajaerial akan sangat berpengaruh dengan keputtusan yang diambil oleh insider yang pada akhirya mempengaruhi nilai perusahaan itu sendiri. Kehadiran kepemilikan saham oleh manajerial bisa mengecilkan konflik yang terjadi berdasarkan teori keagenan selama ini karena diharapkan setiap keputusan yang muncul dari para manajer akan dirasakan langsung manfaatnya oleh mereka dengan memiliki saham perusahaan itu sendiri, sama halnya apabila terjadi kekeliruan maka manajerlah yang akan menanggung risiko kerugian sebagai konsekuensi dari ikut menjadi pemilik saham. Mekanisme untuk menyetarafkan kepentingan manajemen didalam modal perusahaan dinamakan proses 
bonding mechanism. Dengan begitu agency cost of equity dapat ditekan karena adanya kepemilikan manajerial.

Agency cost debt dapat berkuranng dengan adanya kepemilikan institusional dalam rangka efisiensi perusahaan. Kepemilikan saham oleh institusional seperti bank, perusahaan, ataupun perusahaan asuransi juga merupakan salah satu proses pengawasan internal perusahaan. Maka dari itu sesuatu yang relevan jika menghubungkan struktur kepemilikan dalam hal ini kepemilikan institusional dan kepemilikan manajerial terhadap nilai perusahaan.

Selain Kepemilikan Manajerial dan Kepemilikan Institusional, kesulitan lain yang akan dihadapi oleh perusahaan adalah keputusan mengenai pembagian dividen. Dividen adalah pertimbangan utama para investor dalam menyuntikkan dana investasi mereka, dimana dividen adalah pengembalian yang akan diterima investor atas investasinya dalam perusahaan. Para investor memiliki tujuan utama untuk meningkatkan kesejahteraa dengan mengharapkan pengembalian dalam bentuk dividen, sedangkan perusahaan mengharapkan pertumbuhan secara terus menerus untuk mempertahankan kelangsungan hidup perusahaan sekaligus memberikan kesejahteraan kepada para pemegang sahamnya, sehingga kebijakan dividen sangat penting untuk memenuhi harapan pemegang saham terhadap dividen dengan tidak menghambat perumbuhan perusahaan disisi yang lainnya. Keputusan membagi laba atau menahan laba untuk diinvestasikan kembali dalam perusahaan merupakan inti dari Kebijakan Dividen. Atau dengan kata lain Alokasi penentuan laba sebagai laba ditahan dan pembayaran dividen adalah aspek utama dalam kebijakan dividen (Brigham, et al 1999: 479). Ada beberapa perbedaan pendapat mengenai hubungan kebijakan dividen dengan nilai perusahaan. Nilai perusahaan tidak akan naik hanya karena kebijakan dividen yang optimal (Modigliani Miller). Kelompok kedua berpendapat bahwa dividen lebih kecil resikonya dari pada capital gain, oleh karena itu dividen setelah pajak akan meminimumkan biaya modal (GordonLintner). Kelompok ketiga menyatakan bahwa dividen cenderung dikenakan pajak dari pada capital gain. Mereka berpendapat bahwa kebijakan dividen yang lebih rendah akan mengoptimalkan nilai perusahaan.

Investor akan tertarik untuk menanamkan modalnya dengan perusahaan yang nilai perusahaan nya meningkat khususnya capital gain dan dividen. Dalam hal ini keputusan manajer mengenai kebijakan dividen akan dibagikan sebagian atau sekaligus semuanya yang dibagikan sebagai dividen dan selebihnya dicadangkan perusahaan (retained earning). Dividen dapat digunakan untuk mengurangi equity agency cost yang timbul dari adanya perbedaan kepentingan dalam perusahaan. Terkadang pihak manajemen perusahaan mempunyai tujuan yang berbeda dengan tujuan utama perusahaan (agency conflict). Manajer sering kali mementingkan kepentingan pribadi yang menyebabkan biaya sehingga mengurangi laba perusahaan dan dividen yang akan diterima pemegang saham. Kerugian ini adalah agency cost equity bagi perusahaan. Kebijakan dividen juga dipengaruhi oleh beberapa faktor, diantaranya struktur modal yang menggambarkan profitability, ukuran perusahaan, likuiditas, kepemilikan manajerial dan kepemilikan institusional.

Penjelasan diatas secara garis besar menyatakan bahwa menghubungkan kebijakan dividen dengan nilai perusahaan adalah menjadi relevan dan masih menarik untuk di teliti. Maka dari itu penulis mengambil judul "Pengaruh Kepemilikan Manajerial, Kepemilikan Institusional dan Kebijakan Dividen Terhadap Nilai Perusahaan”. Berdasarkan pemaparan isi latar belakang tersebut, maka tujuan penelitian ini adalah untuk mengkaji dan menganalisis:

1. Pengaruh kepemilikan manajerial berpengaruh terhadap nilai perusahaan pada perusahaan otomotif dan komponen periode $2014-2018$

2. Pengaruh kepemilikan institusional berpengaruh terhadap nilai perusahaan pada perusahaan otomotif dan komponen periode $2014-2018$ 
3. Pengaruh kebijakan dividen berpengaruh terhadap nilai perusahaan pada perusahaan otomotif dan komponen periode $2014-2018$

\section{TINJAUAN PUSTAKA DAN PENGEMBANGAN HIPOTESIS}

Nilai yang telah dibayarkan oleh calon pembeli bilamana perusahaan tersebut dijual merupakan nilai perusahaan. Setiap perusahaan pasti ingin meningkatkan nilai perusahaan, karena kemakmuran pemegang saham akan beriringan dengan tingginya nilai perusahaan. Maka dari itu para pemegang saham akan menanamkan modalnya pada perusahaan (Haruman, 2007).

Harga pasar diinterpretasikan sebagai nilai perusahaan. Hal itu karena bila harga saham perusahaan terus meningkat, nilai perusahaan bisa memberikan kemakmuran atau keuntungan bagi pemegang saham secara maksimum. Nilai perusahaan akan meningkat terus menerus seiring dengan menguatnya nilai saham yang berarti juga akan meningkatkan margin dari para pemegang saham, peristiwa ini akan menjadi tolak ukur investor karena permintaan saham akan terus meningkat dengan menguatnya nilai perusahaan. Manajer dan komisaris hadir sebagai orang yang berkompeten untuk mencapai nilai perusahaan yang maksimum. Harga pasar saham perusahaan adalah salah satu aspek untuk mengukur nilai perusahaan. Itu karena harga pasar saham mencerminkan penilaian investor atas keseluruhan ekuitas yang dimiliki oleh perusahaan (Wahyudi dan Pawestri, 2006 dalam Harjadi, Fajarwati, \& Fatmasari, 2018).

Besaran persentase kepemilikan oleh manager dan kepemilikan institusional juga turut menentukan Struktur modal. Terori keagenan menjabarkan bahwa kepentingan pemegang saham dan kepentingan manajemen seringkali bertentangan, sehingga kadangkala terjadi konflik diantara manajemen dan pemegang saham. Manajer terkadang justru lebih mengutamakan kepentingan pribadinya. Sedangkan pemegang saham pastinya tidak akan suka sebabnya akan menambah kepada beban bagi perusahaan yang akan menurunkan margin yang didapatkan (Jensen \& Meckling, 1979).

Bentrokan yang terjadi antara manajer dan pemegang saham dapat dikurangi dengan mensetarakan kepentingan antara keduanya. Dengan masuknya manajer sebagai salah satu pemilik saham dapat digunakan untuk mengurangi agency cost yang terjadi karena dengan ikut mempunyai saham perusahaan diharapkan manajer akan merasakan langsung keuntungan dari tiap keputusan yang diambilnya, begitu juga apabila terjadi kekeliruan maka manajer pastinya akan ikut menanggung kerugian sebagai salah satu imbas dari ikutnya manajer dari kepemilikan saham. Proses ini disebut bonding mechanism, yaitu proses yang dilalui untuk menyetarakan kepentingan manajemen melalui program mengikat manajemen dalam struktur modal perusahaan. Dengan begitu minimalisasi agency cost of equity akan tercapai.

Kepemilikan institusional merupakan kepemilikn saham perusahaan yang dimiliki oleh lembaga institusi seperti prusahaan investasi, bank, prusahaan asuransi dan kepmilikan institusi lain. Kepemilikan institusional mempunyai makna yang berarti dalam mengontrol manajemen keberadaan kepemilikan institusional diharapkan mampu melakukan pengawasan yang lebih optimal. Sehingga jaminan atas kesejahteraan pemegang saham akan terjamin, sebagai agen pengawas pengaruh kepemilikan institusional kepemilikan institusional ditekan melalui investasi mereka yang cukup besar dalam pasar modal.

Kehadiran kepemilikan institusional bisa mengurangi hutang perusahaan dalam rangka mengurangi agency cost of debt. Kepemilikan institusional sendiri berbentuk kepemilikan saham oleh perseorangan dengan nilai diatas $5 \%$ dan perseorangan tersebut tidak masuk dalam jajaran manajemen hal ini disebut blocholder. Wahidahwati (2002), Masdupi (2005). Bila dibandingkan dengan pemegang saham lainnya Institusi pada umumnya akan bias 
mendominasi saham karena besarnya sumber daya yang dimiliki. Pengawasan yang lebih baik dapat dilakukan oleh kepemilikan institusional, karena keuntungan lebih akan didapatkan pihak institusional itu bias dilihat dari segi skala ekonomi untuk memperoleh informasi dan mengkaji hal apapun terkait dengan kebijakan manajer. Selain itu, stabilitas pendapatan atau keuntungan jangka panjang lebih dipentingkan oleh pihak institusional, yang artinya kekayaan penting perusahaan pastinya akan memperoleh pengendalian yang opimal.

Kebijakan dividen merupakan keputusan perusahaan untuk membagi dividen kepada pemegang saham atau menahannya diperusahaan (laba ditahan) dan menjadikannya pembiayaan untuk menunjang investasi mendatang. Bukan pilihan mudah bagi perusahaan untuk memilih menahan datau membagikan laba karena dalam kebijakan dividen juga terdapat trade off yang harus diperhatikan.

Jika pilihan jatuh kepada membagikan margin sebagai dividen maka tingkat perkembangan perusahaan akan berkurang dan berdampak negatif terhadap saham. Disisi lain, jika deviden tidak dibagikan maka dampak negative akan terlihat di sector pasar kepada prospek perusahaan. Apabila terjadi peningkatan dividen maka akan memberikn perubahan yang menguntungkan pada harapan manajer dan bila terjadi penurunan dividen maka akan menunjukkan pandangan negative pada prospek perusahaan dimasa mendatang.

\section{Pengembangan Hipotesis}

Berdasarkan telaah penelitian oleh Alfiantoro (2016), Wahyudi \& Pawestri (2006), bahwa kepemilikan manajerial berpengaruh positif sedangkan penelitian oleh Permanasari (2010), Wida P.D \& Suartana, (2014) bahwa kepemilikan manajerial berpengaruh negatif terhadap nilai perusahaan. Berdasarkan uraian diatas maka hipotesis yang diajukan:

H1: Kepemilikan Manajerial berpengaruh positif dan signifikan terhadap Nilai Perusahaan

Berdasarkan telaah penelitian oleh Wida P.D \& Suartana (2014), Alfiantoro (2016), Purba \& Effendi (2019), bahwa kepemilikan institusional berpengaruh positif sedangkan penelitian oleh Permanasari (2010), Wahyuningsih (2015) bahwa kepemilikan institusional berpengaruh negatif terhadap nilai perusahaan. Berdasarkan uraian diatas maka hipotesis yang diajukan:

H2: Kepemilikan Institusional berpengaruh Positif dan signifikan terhadap Nilai Perusahaan

Berdasarkan telaah penelitian oleh Wahyuningsih (2015), Fenandar (2012), Alfiantoro (2016), Wati \& Darmayanti (2012) bahwa kebijakan Dividen berpengaruh positif terhadap nilai perusahaan.Berdasarkan uraian diatas maka hipotesis yang diajukan:

H3: Kebijakan Dividen berpengaruh positif dan signifikan terhadap Nilai Perusahaan

\section{Kerangka Pikir}

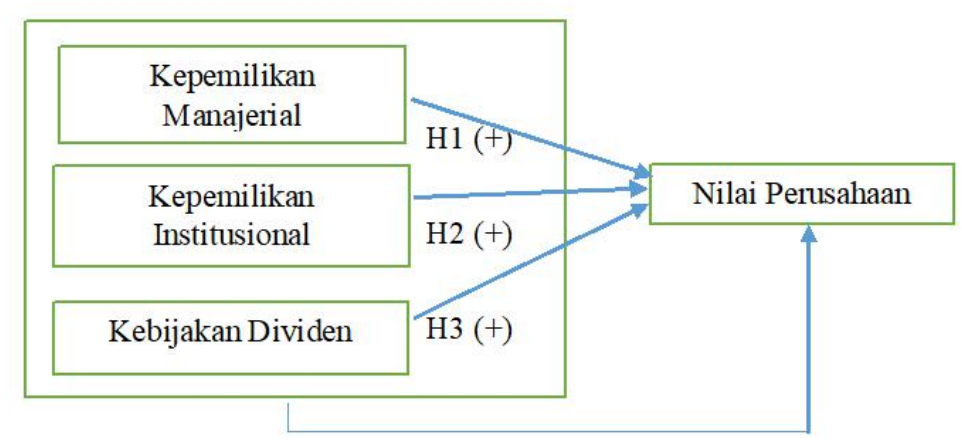




\section{Gambar 1. Kerangka Pemikiran}

\section{METODE PENELITIAN}

Obyek penelitian ini yaitu laporan keuangan perusahan otomotif dan komponen yang terdaftar di Bursa Efek Indonesia (BEI) dengan periode yang digunakan 2014-2018. Data akan yang digunakan dalam penelitian ini merupakan data kuantitatif yang berupa laporan keuangan perusahaan industri otomotif dan komponen. Data yang diperoleh merupakan data sekunder berasal dari Bursa Efek Indonesia (BEI) dengan periode yang digunakan 2014-2018.

Populasi dalam penelitian ini adalah seluruh perusahaan otomotif dan komponen yang terdaftar di Bursa Efek Indonesia (BEI) selama tahun 2014-2018. Sampel penelitian ini merupakan sektor industri. Metode pengambilan sampel yang digunakan dalam penelitian ini yaitu non probability sampling dengan menggunakan purposive sampling. Purposive sampling adalah teknik penentuan sampel dengan berdasrkan pada kriteria - kriteria tertentu.

Penghimpunan data dalam penelitian ini menggunakan Teknik dokumentasi, yaitu dengan cara mengumpulkan, lalu mencatat dan kemudian mengolah data sekunder berupa laporan keuangan perusahaan industri otomotif dan komponen yang terdaftar dan dipublikasikan oleh Bursa Efek Indonesia (BEI) dengan periode yang digunakan 2014-2018. Pengujian hipotesis yang akan dilakukan pada penelitian ini menggunakan uji regresi linier berganda, uji $\mathrm{T}$ (pengujian secara parsial), dan uji $\mathrm{F}$ (pengujian secara stimultan).

\section{HASIL DAN PEMBAHASAN Uji Statistik Deskriptif}

Tabel 1. Hasil Analisis Deskriptif Statistik

\begin{tabular}{lrrrrr}
\hline & N & Minimum & Maximum & Mean & Std. Deviation \\
KM & 46 & .000 & .280 & .04641 & .073681 \\
KI & 46 & .490 & .897 & .67257 & .148555 \\
DPR & 46 & .000 & .867 & .23582 & .257505 \\
PBV & 46 & .120 & 6.094 & 1.41524 & 1.413668 \\
Valid N (listwise) & 46 & & & & \\
\hline
\end{tabular}

Sumber Data : Data diolah SPSS 23

Variabel Kepemilikan Manajerial ditunjukkan oleh proksi KM memiliki nilai minimum sebesar 0,000; nilai maximum 0,280; nilai mean 0,04641; dan memiliki standar deviasi sebesar 0,073681. Variabel Kepemilikan Institusional ditunjukkan oleh proksi KI memiliki nilai minimum sebesar 0,490 ; nilai maximum 0,897 ; nilai mean 0,67257 ; dan memiliki standar deviasi sebesar 0,148555. Variabel Kebijakan Dividen ditunjukkan oleh proksi DPR memiliki nilai minimum sebesar 0,000 ; nilai maximum 0,867 ; nilai mean 0,23582 ; dan memiliki standar deviasi sebesar 0,257505. Variabel Nilai Perusahaan yang ditunjukkan oleh proksi PBV memiliki nilai minimum sebesar 0,120; nilai maximum 6,094; nilai mean 1,41524; dan memiliki standar deviasi sebesar 1,413668.

\section{Uji Asumsi Klasik}

Uji Normalitas

Tabel 2. Hasil Analisis Uji Normalitas

\begin{tabular}{cc}
\hline Asymp. Sig (2-tailed) & .200 \\
\hline Sumber : Data diolah SPSS 23
\end{tabular}

Hasil uji Kolmogorov-Smirnov pada tabel 2 menunjukkan tingkat probabilitas signifikansi sebesar 0,200. Karena nilai p lebih dari 0,05, maka dapat disimpulkan bahwa data residual terdistribusi secara normal. 


\section{Uji Autokorelasi}

\section{Tabel 3. Hasil Analisis Uji Autokorelasi}

\begin{tabular}{cc}
\hline Asymp. Sig (2-tailed) & .180 \\
\hline Sumber : Data diolah SPSS 23
\end{tabular}

Berdasarkan tabel 3 hasil Runs test sebesar 0,180 maka nilai ini diatas standar Asymp.Sig sehingga dapat disimpulkan bahwa model regresi linier tidak terjadi autokorelasi.

\section{Uji Multikolonieritas}

\begin{tabular}{|c|c|c|c|}
\hline & \multirow[t]{2}{*}{ Model } & \multicolumn{2}{|c|}{$\begin{array}{l}\text { Collinearity } \\
\text { Statistics }\end{array}$} \\
\hline & & Tolerance & VIF \\
\hline \multirow[t]{4}{*}{1} & (Constant) & & \\
\hline & KM & .804 & 1.245 \\
\hline & KI & .807 & 1.239 \\
\hline & DPR & .972 & 1.029 \\
\hline
\end{tabular}

Berdasarkan tabel 4 menunjukkan bahwa tidak ada satupun variabel bebas yang memiliki nilai tolerance dibawah 0,10 dan nilai Variance Inflation Factor (VIF) di atas 10. Jadi dapat disimpulkan bahwa tidak terjadi multikolonieritas antar variabel bebas.

\section{Uji Heterokedastisitas}

Tabel 5. Hasil Analisis Uji Heterokedastisitas

\begin{tabular}{cc}
\hline & Sig. (2-tailed) \\
KM & .170 \\
KI & .937 \\
DPR & .937 \\
\hline
\end{tabular}

Sumber : Data diolah SPSS 23

Berdasarkan tabel 5 hasil regresi menunjukkan bahwa seluruh variabel independen mempunyai nilai yang tidak signifikan sehingga dapat disimpulkan bahwa dalam regresi ini tidak terjadi gejala heterokedastisitas

\section{Uji Koefisien Determinasi $\left(\mathbf{R}^{2}\right)$}

Tabel 6. Hasil Analisis Uji Adjusted R Square

\begin{tabular}{cc}
\hline Adjusted R Square & .325 \\
\hline Sumber : Data diolah SPSS 23
\end{tabular}

Berdasarkan tabel penelitian 6 diketahui bahwa nilai adjusted $\mathrm{R}$ square sebesar 0,325. Hal ini berarti bahwa $32,5 \%$ nilai perusahaan dapat dijelaskan oleh variasi variabel independen yaitu kepemilikan manajemen, kepemilikan institusional, dan kebijakan Dividen, sisanya sebesar $67,5 \%(100 \%-32,5 \%)$ dijelaskan oleh sebab-sebab lain diluar model. 
Tabel 7. Uji T ( Parsial)

\begin{tabular}{lrrrr}
\hline Model & B & & t & Sig. \\
\hline Constant) & 2.416 & 3.431 & .001 \\
KM & .610 & 1.315 & .196 \\
KI & -2.066 & -2.493 & .017 \\
DPR & .680 & 3.396 & .002 \\
\hline
\end{tabular}

Sumber : Output Spss 23

Hasil uji diatas menunjukan bahwa hasil estimasi variabel kepemilikan manajerial (KM) terhadap nilai perusahaan (PBV) memiliki koefisien $\mathrm{t}$ sebesar 1,315 dengan signifikansi sebesar 0,196. Hasil ini menunjukkan bahwa variabel kepemilikan manajerial (KM) memiliki arah yang positif dan tidak signifikan terhadap nilai perusahaan (PBV). Maka hipotesis peneliti yang menyatakan bahwa kepemilikan manajerial berpengaruh positif dan signifikan terhadap nilai perusahaan ditolak.

Pengujian hipotesis menunjukkan kepemilikan manajerial tidak berpengaruh signifikan terhadap nilai perusahaan. Nilai koefisien regresi yang positif hal ini membuktikan bahwa naikknya kepemilikan manajemen di dalam suatu perusahaan maka menaikkan nilai perusahaan. kepemilikan saham oleh manajer dapat menjadi solusi dari konflik kepentingan antara principal dan agen. Manajer akan melakukan langkah nyata untuk menaiikan nilai perusahaan karena perannya yang ikut andil sebagai pemegang saham, sebab kemakmurannya juga akan turut meningkat.

Hasil yang tidak signifikan disebabkan struktur kepemilikan manajerial di Indonesia masih sangat kecil dan didominasi oleh keluarga, sehingga kurang mampu melakukan kontrol terhadap jalannya perusahaan. Rendahnya saham yang dimiliki oleh manajemen menyebabkan belum adanya rasa memiliki yang timbul oleh manajemen disebabkan manfaat yang dinikmati oleh manajemen hanya sebagian saja, hal itu yang menimbulkan tidak maksimalnya kinerja manajemen dalam memaksimalkan utilitasnya sehingga pemegang saham dirugikan. Selain itu kinerja yang cenderung rendah juga dipicu oleh sedikitnya nilai kepemilikan saham manajemen yang menyebabkan proses pengambilan keputusan yang terkait dengan nilai perusahaan dalam proses pengambilan keputusan manajer tidak begitu berpengaruh atau masih kurang.

Penelitian yang dilakukan Andriyawandi (2016) dan Agustiany (2018) yang menemukan kepemilikan manajerial berpengaruh positif dan tidak signifikan terhadap nilai perusahaan sesuai dengan hasil yang diperoleh.

\section{Analisis Pengaruh Kepemilikan Institusional Terhadap Nilai Perusahaan}

Berdasarkan hasil perhitungan diatas, didapatkan hasil estimasi variabel kepemilikan institusional (KI) terhadap nilai perusahaan (PBV) memiliki koefisien $t$ sebesar $-2,493$ dengan signifikansi sebesar 0,017. Hasil ini menunjukkan bahwa variabel kepemilikan institusional (KI) memiliki arah yang negatif dan tidak signifikan terhadap nilai perusahaan (PBV). Hasil ini menunjukkan bahwa hipotesis penelitian ini ditolak.

Tinggi rendahnya tingkat prosentase kepemilikan saham institusional di sebuah perusahaan tidak begitu mempengaruhi nilai perusahaan, sebab pihak institusi tidak bisa mengawasi manajemen dengan baik, karena para investor institusi berinvesi di beberapa perusahaan yang saling berkaitan sehingga investor institusi lebih cenderung berpihak kepada keputusan manajer jadi kepemilikan institusional tidak ikut berperan dalam pengambilan keputusan, sehingga para investor tidak melihat tingkat besar dan kecilnya kepemilikan institusional sehingga tidak berpengaruh terhadap harga saham dan nilai 
perusahaan. Sejalan dengan penelitian yang dilakukan oleh Asyra (2017) yang menjelaskan bahwa kepemilikan institusional berpengaruh negatif dan tidak signifikan terhadap nilai perusahaan.

\section{Analisis Pengaruh Kebijakan Dividen Terhadap Nilai Perusahaan}

Berdasarkan hasil dari perhitungan, didapatkan hasil estimasi variabel kebijakan deviden (DPR) terhadap nilai perusahaan (PBV) memiliki koefisien t sebesar 3,396 dengan signifikansi sebesar 0,002. Hasil ini menunjukkan bahwa variabel kebijakan deviden (DPR) memiliki arah yang positif dan signfikan terhadap nilai perusahaan (PBV). Sehingga hipotesis peneliti yang mengemukakan bahwa kebijakan deviden berpengaruh positif dan signifikan terhadap nilai perusahaan diterima.

Hasil menjelaskan jika kebijakan deviden yang di proksikan dengan Dividen Payout Ratio yang semakin tinggi mempengaruhi nilai perusahaan. Para pemegang saham bias mendapatkan kemakmuran bila perusahaan mempunyai kas yang murni bebas, yang artinya dapat dibagikan kepada pemilik saham sebagai dviden. Apabila tingkat kesehatan perusahaan terus meningkat, hal itu berdampak pada keyakinan para pemegang saham untuk bias mendapatkan keuntungan (dividen atau capital gain) dimasa yang akan datang.

Dari hasil penelitian ini membuktikan salah satu usaha yang dapat dilakukann perusahaan untuk menerapkan mekanisme kontrol selain dengan adanya kepemilikan institusional dan kepemilikan manajerial yaitu dengan pembagian deviden, cara ini juga merupakan salah satu mekanisme kontrol yang dapat dilakukan perusahaan dikarenakan pembagian deviden dapat mengurangi ketidakpastian dan mengurangi resiko walaupun melalui manajerialship tidak berjalan dibuktikan dari hasil kepemilikan manajerial yang tidak signifikan, sehingga dengan pembagian deviden dapat mengurangi kecenderungan manajer untuk berperilaku oportunistik yaitu bertindak untuk mengejar kepentingan mereka sendiri atau perilaku manajer yang bertindak dalam kepentingan terbaik bagi dirinya,dan tidak dalam kepentingan terbaik bagi para pemegang saham. Ketika perusahaan beresiko investor akan menaikkan expected returnnya dengan kata lain deviden yang diharapkan investor juga akan naik karena setiap investor pasti menginginkan keuntungan selain dari pembagian deviden yaitu dari capital gain. Hal ini sangat berbeda dengan manajer perusahaan dimana seorang manajer lebih menyukai resiko yang rendah sedangkan seorang investor lebih menyukai resiko yang tinggi, karena resiko yang tinggi menjanjikan return yang tinggi bagi investor.

Penelitian ini mendukung teori bird in the hand yang menyatakan investor lebih menyukai laba yang didapatkan perusahaan dibagikan dalam bentuk deviden dibandingkan dengan laba ditahan dikarenakan pembagian deviden dapat mengurangi ketidakpastian dan mengurangi resiko. Sesuai dengan signaling theory, kenaikan pembayaran dividen merupakan sinyal yang diberikan oleh perusahaan bagi investor bahwa prospek perusahaan yang akan datang akan semakin baik, dividen yang dibagikan kepada investor merupakan salah satu indikator bahwa perusahaan memiliki kesempatan untuk tumbuh dimasa yang akan datang,sehingga investor akan tertarik dengan membeli saham perusahaan, peningkatan permintaan saham yang tinggi akan selaras dengan harga saham yang juga tinggi dengan harga saham yang tinggi bisa meningkatkan nilai perusahaan.

Penelitian ini sejalan dengan penelitian dari Eva Agustiany (2018), Alyaning Widya (2018) dan Asyra (2018) yang menemukan kebijakan deviden berpengaruh positif dan signifikan terhadap nilai perusahaan. Semakin besar dividen yang dibagikan yang meningkat setiap tahunnya, maka banyak investor yang tertarik untuk membeli saham perusahaan yang pada akhirnya akan meningkatkan nilai perusahaan. 


\section{Analisis Pengaruh Kepemilikan Manajerial, Kepemilikan Insttusional dan Kebijakan Dividen Terhadap Nilai Perusahaan}

Tabel 8. Uji F (Stimultan)

\begin{tabular}{|c|c|c|c|}
\hline Model & $\mathrm{F}$ & & \\
\hline Regresi Residual Total & & 8.227 & $.000^{\mathrm{b}}$ \\
\hline
\end{tabular}

Sumber : Output Spss 23

Berdasarkan tabel penelitian 4.8 hasil uji F menunjukkan bahwa nilai signifikan sebesar 0,000 lebih kecil dari taraf signifikan yang telah ditentukan sebesar 0,05 yang berarti terdapat pengaruh signifikan secara simultan antara variabel independen dengan variabel dependen, hal ini membuktikan bahwa secara simultan nilai perusahaan dipengaruhi oleh kepemilikan manajemen, kepemilikan insttusional, dan kebijakan deviden.

\section{PENUTUP}

Berdasarkan dari kajian data dan pembahasan maka dapat disimpulkan bahwa: kepemilikan manajerial (KM) berpengaruh positiif dan tidak signfikan bagi nilai perusahaan (PBV). Kepemilikan Institusional (KI) berpngaruh negatif dan tidak signfikan terhadap nilai perusahaan (PBV). Kebijakan Deviden (DPR) berpengaruh positif dan signifikan terhadap nilai perusahaan (PBV) sedangkan kepemilikan manajerial, kepemilikan institusional dan kebijakan deviden secara bersama-sama atau simultan berpengaruh positif dan signifikan terhadap nilai perusahaan.

Berdasarkan analisis dan pembahssan dari penelitian ini, maka peneliti menyarankan bagi perusahaan yang menjadi objek dalam penelitian ini disarankan untuk mempertimbangkan untuk memperbesar dividend payout ratio-nya karena berdasarkan analisis kebijakan tersebut mampu meningkatkan price book value. Bagi peneliti selanjutnya disarankan untuk memperluas sampel ke sector industry lain, lalu menggali dan memperhatikan lagi $67,5 \%$ faktor-faktor lain seperti leverage dan Profitabilitas yang tidak disertakan dalam penelitian ini yang dapat mempengaruhi nilai perusahaan.

\section{DAFTAR PUSTAKA}

Agustiany, Eva. 2018. "Pengaruh Kepemilikan Manajerial, Kebijakan Dividen Perilaku Oportunistik Dan Profitabilitas Terhadap Nilai Perusahaan Sektor Manufaktur Yang Terdaftar Di Bursa Efek Indonesia 2011-2015."

Alfiantoro, Teguh. 2016. "Pengaruh Kepemilikan Manajerial, Kepemilikan Institusional, Kebijakan Deviden, Kebijakan Hutang Dan Kebijakan Investasi Terhadap Nilai Perusahaan Pada Sektor Manufaktur Di Bursa Efek Indonesia Periode 2011-2014." Andriyawandi. 2016. "Analisis Pengaruh Kinerja Keuangan, Kepemilikan Manajerial

Dan Corporate Social Responsibility Terhadap Nilai Perusahaan."

Asyra, Muhammad. 2017. "Pengaruh Kebijakanv Dividen, Leverage, Profitabilitas, Dan Kepemilikan Institusional Terhadap Nilai Perusahaan."

Bringham, E. F. and Houston. 2001. Manajemen Keuangan. delapan. Jakarta: Salemba Empat.

Ermiati, Cut, Dita Amanah, Dedy Ansari Harahap, and Eva Santi Siregar. 2019. "Pengaruh Kebijakan Dividen Terhadap Harga Saham Perusahaan Sub Sektor Otomotif Dan Komponen Yang Terdaftar Di Bursa Efek Indonesia.” 8(2). 
Fenandar, Gany Ibrahim. 2012. "Pengaruh Keputusan Investasi, Keputusan Pendanaan, Dan Kebijakan Dividen Terhadap Nilai Perusahaan."

Harjadi, D., Fajarwati, N., \& Fatmasari, D. (2018). Pengaruh Kepemilikan Institusional dan Leverage terhadap Nilai Perusahaan. Al-Amwal: Jurnal Ekonomi dan Perbankan Syari'ah, 10(2), 245-258.

Haruman, T. (2007). Pengaruh Keputusan Keuangan dan Kepemilikan Institusional terhadap Nilai Perusahaan (Studi Kasus Pada Perusahaan Manufaktur Yang Listing di BEJ). The 1st PPM National Conference on Management Research, Sekolah Tinggi Manajemen PPM Jakarta.

Jensen, M. C., \& Meckling, W. H. (1979). Theory of the firm: Managerial behavior, agency costs, and ownership structure. In Economics social institutions (pp. 163-231). Springer, Dordrecht.

Masdupi, E. (2005). Analisis dampak struktur kepemilikan pada kebijakan hutang dalam mengontrol konflik keagenan. Jurnal Ekonomi dan Bisnis Indonesia, 20(2005).

Permanasari, Wien Ika. 2010. "Pengaruh Kepemillikan Manajemen, Kepemilikan Institusional, Dan Corporate Social Responsiibility Terhadap Nilai Perusahaan.”

Purba, Neni Marlina Br and Syahril Effendi. 2019. "Pengaruh Kepemilikan Manajerial Dan Kepemillikan Institusional Terhadap Nilai Perusahaan Pada Perusahaan Manufaktur Yang Terdaftar Di BEI.” 3(2).

Wahidahwati, W. (2002). Pengaruh kepemilikan manajerial dan kepemilikan institusional pada kebijakan hutang perusahaan: Sebuah perspektif theory agency. The Indonesian Journal of Accounting Research, 5(1).

Wahyudi, Untung and Hartini Prasetyaning Pawestri. 2006. "Implikasi Struktur Kepemilikan Terhadap Nilai Perusahaan Dengan Keputusan Keuangan Sebagai Variabel Intervening."

Wahyuningsih, Diah. 2015. "Pengaruh Kepemilikan Manajerial, Kepemilikan Institusional, Kebijakan Deviden, Kebijakan Hutang Dan Maanajemen Laba Terhadap Nilai Perusahaan."

Wati, Ni Kadek Ari Lina and Ni Putu Ayu Darmayanti. 2012. "Pengaruh Kepemilikan Manajerial Dan Kinerja Keuangan Terhadap Kebijakan Dividen Dan Nilai Perusahaan."

Wida P.D, Ni Putu and I. Wayan Suartana. 2014. "Pengaruh Kepemilikan Manajerial Dan Kepemilikan Institusional Pada Nilai Perusahaan.” 3.

Widya, Alyaning. 2018. "Pengaruh Kepemilikan Manajerial, Kepemilikan Institusional, Kebijakan Deviden, Dan Kebijakan Hutang Terhadap Nilai Perusahaan."

Yahdi, Rahima and Aminar Sutra Dewi. 2015. "Pengaruh Sturktur Modal, Ukuran Perusahaan, Dan Profitabilitas Terhadap Nilai Perusahaan Otomotif Yang Terdaftar Di BEI Periode 2012-2016." Jurnal Dinamika Akuntansi 7(2). 